\title{
Nariz en silla de montar
}

\section{Saddle Nose Deformity}

\author{
Alexandra Elbers ${ }^{1, a}$, André Aquiles Carbajal ${ }^{1, a}$, Juan D. Carballo ${ }^{1, a}$, José Coz ${ }^{1, a}$, Vivian Díaz ${ }^{1, a}$, Ángelo \\ Falconi $^{1, a}$, Armando Calvo ${ }^{1, b}$
}

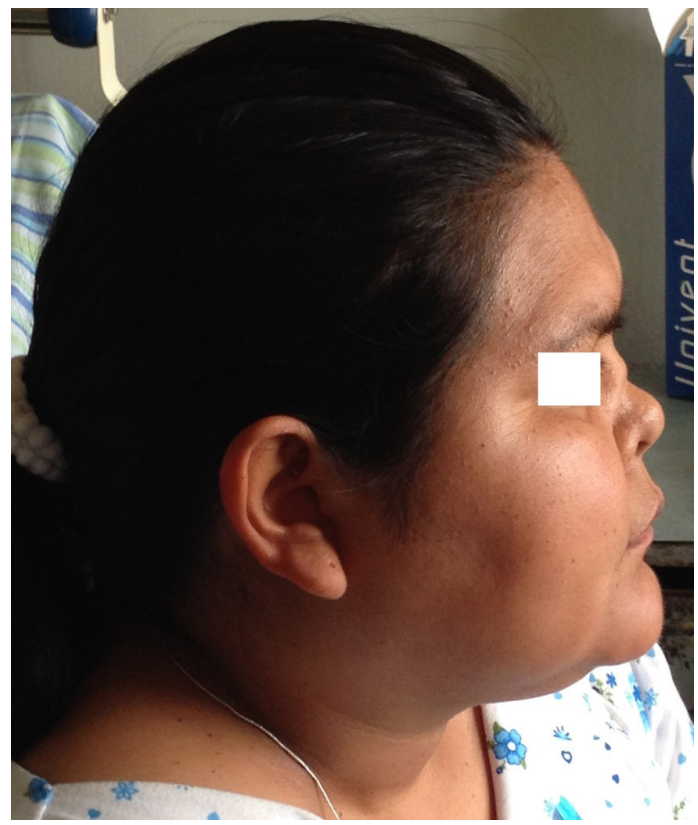

Mujer de 41 años, con diagnóstico de granulomatosis con poliangeitis de 8 años de evolución. Al examen físico se evidencia nariz en silla de montar. La nariz en silla de montar ocurre por destrucción del tabique nasal. La afectación del seno nasal es la manifestación más común de la granulomatosis con poliangeitis, encontrándose hasta en $85 \%$ de los pacientes. Signos clásicos son la erosión y lisis del cartílago nasal, que pueden conducir a perforación del septo nasal y deformación de la nariz en silla de montar, algunas veces con formación de fístula de la órbita sinusal o del seno palatino. La perforación del septo nasal ocurre generalmente en el área del plexo de Kiesselbach. El diagnóstico diferencial de la nariz en silla de montar incluye: Síndrome del linfocito desnudo, policondritis recidivante, sífilis congénita, neoplasia del seno paranasal, linfoma de la línea media, trauma, sarcoidosis y Lepra (menos común).

41 year old woman diagnosed of granulomatosis with polyangiitis 8 years of evolution. Physical examination evidenced nose saddle deformity. The saddle nose deformity occurs due to destruction of the nasal septum. Involvement of the sinus is the most common manifestation of granulomatosis with polyangiitis, being up to $85 \%$ of patients. Classic signs are erosion and lysis of the nasal cartilage, which may lead to perforation of the nasal septum and deformation of the saddle nose, sometimes with fistula formation sinus or orbit palatine sinus. Perforation of the nasal septum usually occurs in the area Kiesselbach plexus. The differential diagnosis of saddle nose includes: bare lymphocyte syndrome, relapsing polychondritis, congenital syphilis, neoplasm of the paranasal sinus, middle lymphoma, trauma, sarcoidosis and leprosy (less common).

\footnotetext{
1 Facultad de Medicina Alberto Hurtado, Universidad Peruana Cayetano Heredia. Lima, Perú.

b Profesor Principal
} 